\title{
THE
}

UNIVERSITY

University of Rhode Island

OF RHODE ISLAND

DigitalCommons@URI

6-30-2018

\section{Citric Acid Based Pre-SEI for Improvement of Silicon Electrodes in Lithium Ion Batteries}

\author{
K. W. D. Kaveendi Chandrasiri \\ University of Rhode Island \\ Cao Cuong Nguyen \\ University of Rhode Island \\ Bharathy S. Parimalam \\ University of Rhode Island \\ Sunhyung Jurng \\ University of Rhode Island \\ Brett L. Lucht \\ University of Rhode Island, blucht@uri.edu
}

Follow this and additional works at: https://digitalcommons.uri.edu/chm_facpubs

Creative Commons License

(c) (i)

This work is licensed under a Creative Commons Attribution 4.0 License.

\section{Citation/Publisher Attribution}

Chandrasiri, K.W.D.K., Nguyen, C.C., Parimalam, B.S., Jurng, S., Lucht, B.L. Citric acid based Pre-SEl for improvement of silicon electrodes in lithium ion batteries (2018) Journal of the Electrochemical Society, 165(10), pp. A1991-A1996. DOI: 10.1149/2.0161810jes

Available at: http://dx.doi.org/10.1149/2.0161810jes

This Article is brought to you for free and open access by the Chemistry at DigitalCommons@URI. It has been accepted for inclusion in Chemistry Faculty Publications by an authorized administrator of DigitalCommons@URI. For more information, please contact digitalcommons-group@uri.edu. 


\title{
Citric Acid Based Pre-SEI for Improvement of Silicon Electrodes in Lithium Ion Batteries
}

\author{
K. W. D. Kaveendi Chandrasiri, Cao Cuong Nguyen,* Bharathy S. Parimalam, \\ Sunhyung Jurng, $\odot$ and Brett L. Lucht $\oplus^{*, z}$
}

The Richard E. Beaupre Center for Chemical and Forensic Sciences, University of Rhode Island, Kingston, Rhode Island 02881, USA

\begin{abstract}
Silicon electrodes are of interest to the lithium ion battery industry due to high gravimetric capacity $(\sim 3580 \mathrm{mAh} / \mathrm{g})$, natural abundance, and low toxicity. However, the process of alloying and dealloying during cell cycling, causes the silicon particles to undergo a dramatic volume change of approximately $280 \%$ which leads to electrolyte consumption, pulverization of the electrode, and poor cycling. In this study, the formation of an ex-situ artificial SEI on the silicon nanoparticles with citric acid has been investigated. Citric acid (CA) which was previously used as a binder for silicon electrodes was used to modify the surface of the nanoparticles to generate an artificial SEI, which could inhibit electrolyte decomposition on the surface of the silicon nanoparticles. The results suggest improved capacity retention of $\sim 60 \%$ after 50 cycles for the surface modified silicon electrodes compared to $45 \%$ with the surface unmodified electrode. Similar improvements in capacity retention are observed upon citric acid surface modification for silicon graphite composite/ $\mathrm{LiCoO}_{2}$ cells.

(c) The Author(s) 2018. Published by ECS. This is an open access article distributed under the terms of the Creative Commons Attribution 4.0 License (CC BY, http://creativecommons.org/licenses/by/4.0/), which permits unrestricted reuse of the work in any medium, provided the original work is properly cited. [DOI: $10.1149 / 2.0161810 \mathrm{jes}]$

(cc) BY
\end{abstract}

Manuscript submitted May 1, 2018; revised manuscript received June 18, 2018. Published June 30, 2018.

Lithium ion batteries have been widely used in the portable electronic device market for over two decades due to high energy density, good rate capability, and long cycle life. ${ }^{1-3}$ Graphite is the most frequently used commercial anode material. Although graphite has good performance, low cost and high capacity retention, the relatively modest storage capacity ( $370 \mathrm{mAh} / \mathrm{g}$ ) has driven investigations of alternative anode materials. ${ }^{4}$ Different anode materials with greater storage capacity have been investigated including lithium metal, tin, silicon and other metal alloys. While lithium metal anodes are very appealing, dendrite formation after long term cycling results in significant safety concerns. $^{5-7}$ Therefore, the use of lithium alloying compounds has been intensively investigated over the last decade. Silicon is the most attractive alloying anode material due to its high theoretical capacity. Lithiation of silicon results in the formation of alloys such as $\mathrm{Li}_{15} \mathrm{Si}_{4}$ with a theoretical capacity of $3580 \mathrm{mAh} / \mathrm{g} .{ }^{8}{ }^{8} \mathrm{In}$ addition, silicon has a high volumetric capacity of $9786 \mathrm{mAh} / \mathrm{cm}^{3} .{ }^{10}$

Silicon is abundant and has low toxicity which makes it a good candidate for an anode material for commercial batteries. Silicon also exhibits a discharge voltage of $\sim 0.4 \mathrm{~V}$ vs $\mathrm{Li} / \mathrm{Li}^{+}$which allows it to maintain an open circuit potential which avoids lithium plating. ${ }^{9,11-13}$ While theoretically interesting, there are numerous factors that make silicon electrode use difficult. Some of the important factors include the volume variation during the lithiation and delithiation process of $280 \%$ which leads to pulverization of the electrode, instability of the SEI due to the volume variation, and damage to the electrode laminate. ${ }^{14,15}$ Numerous strategies have been undertaken to solve these stress induced problems that affect the electrochemical properties of the electrode including the use of nanoparticles, which limit the stress induced damage from large volume changes, ${ }^{16,17}$ containing the capacity of silicon to $1200 \mathrm{mAh} / \mathrm{g},{ }^{18}$ the use of electrolyte additives for better SEI formation, ${ }^{19}$ novel binders that can accommodate the stress or modify the surface of the silicon particles ${ }^{20,21}$ and structure modification of the electrode materials. ${ }^{22}$

This investigation is focused on improving the interfacial properties of the silicon electrode by using surface modification. Citric acid (CA) has been previously reported as a binder for silicon-based anodes. ${ }^{23}$ The use of citric acid binder provided comparable electrochemical performance to silicon anodes prepared with poly(acrylic acid) (PAA), one of the better binders reported for silicon anodes..$^{24,25}$ Ex-situ surface analysis of the citric acid based anodes indicates that the citric acid decomposes on the surface of the electrode to form

\footnotetext{
*Electrochemical Society Member.
}

${ }^{\text {z}}$ E-mail: blucht@chm.uri.edu lithium citrate which functions as a pre-formed SEI. Our previous manuscript investigated the use of citric acid as a binder for silicon anodes. ${ }^{25}$ In this manuscript, we investigate citric acid as a pre-treating agent to modify the surface of the silicon particles, which therein could generate an artificial SEI on the silicon particles. The use of citric acid as a surface modifying agent also allows the use of citric acid modified silicon in silicon/graphite composite electrodes.

\section{Experimental}

Silicon nanoparticles ( $<50 \mathrm{~nm}$, Alfa Aesar), Super C (Timcal), Graphite G8 (C-preme), SFG6 (Timcal), Anhydrous NMP (sigma Aldrich), PVDF binder ( $\mathrm{M}_{\mathrm{w}}=600$ 000, MTI), and Citric Acid (CA) (99.5\%, Acros organics) were purchased. Battery grade Lithium hexafluorophosphate $\left(\mathrm{LiPF}_{6}\right)$, Ethylene Carbonate (EC), Dimethyl Carbonate (DMC) and Fluoroethylene Carbonate (FEC) were obtained from a commercial supplier with water content $<50 \mathrm{ppm}$ and stored in an Ar glove box. High purity lithium chips (15.6 mm diameter) were purchased from MTI corporation.

Surface modification of silicon nanoparticles with citric acid.Surface modification was carried out through sonication and subsequent stirring of silicon nanoparticles (Si-np) and citric acid in NMP. $10 \%$ citric acid solution was prepared via sonication of citric acid with NMP for 30 minutes. $0.2 \mathrm{~g}$ of silicon nanoparticles were sonicated for three hours in $20 \mathrm{~mL}$ of $10 \%$ citric acid-NMP solution. The mixture was stirred for 12 hours with 10 minutes of sonication every 3 hours to prevent aggregation of the nanoparticles. The particles were collected with centrifugal separation, washed twice with NMP to remove the unreacted citric acid, and washed 3 times with acetone to remove the residual NMP. The samples were dried under air at $40^{\circ} \mathrm{C}$ in a convection oven for 2 hours and transferred to a vacuum oven at $35^{\circ} \mathrm{C}$ and dried for 24 hours. The same procedure was repeated two more times to complete the surface modification. The samples were analyzed using infrared spectroscopy with attenuated total reflectance (IR-ATR) to confirm the formation of the silyl ester bonds.

Preparation of silicon and silicon graphite composite electrode laminates.-Laminates were prepared with both fresh silicon nanoparticles (Si-np) and modified silicon nanoparticles (M-Si-np). Citric acid, PVDF, graphite and carbon black powders, were dried in a vacuum oven overnight at $110^{\circ} \mathrm{C}$, and Si-np powder was dried for 48 hours in a vacuum oven at $35^{\circ} \mathrm{C}$ before slurry preparation. The electrode slurry was prepared in a nitrogen filled glove box, to minimize agglomeration of the nanoparticles, oxidization in air, and reaction 
with moisture. ${ }^{26}$ The fresh Si-np or M-Si-np, super C65 conductive carbon, and PVDF binder were mixed thoroughly in 2:1:1 ratio using a mortar and pestle with extra dry NMP as a solvent for one hour.

Subsequently the mixture was stirred for 3 hours using a magnetic stirrer and then coated on copper foil using a doctor blade. The laminates were dried in a convection oven under air flow for one hour and dried overnight under vacuum at room temperature. Electrodes were punched with $14 \mathrm{~mm}$ diameter and dried under vacuum at $110^{\circ} \mathrm{C}$ for another 24 hours and transferred into an argon filled glove box for coin cell preparation.

Similarly, silicon nanoparticle graphite composite electrodes were prepared with Si-np or M-Si-np, Super C -65, Graphite SFG6, Graphite G8, and PVDF binder at a ratio of 15:5:30:40:10 using mortar and pestle and NMP as a solvent in a $\mathrm{N}_{2}$ filled glove box.

Cell construction.-Coin cells (2032 type) were constructed in an argon filled glove box. Cells were assembled using a $14 \mathrm{~mm} \mathrm{Si-np}$ anode, one $19 \mathrm{~mm}$ Celgard 2325 separator, one $15.6 \mathrm{~mm}$ Whatman GF/D glass microfiber separator, and a $15.6 \mathrm{~mm}$ lithium chip with $100 \mu \mathrm{L}$ of electrolyte containing $1.2 \mathrm{M} \mathrm{LiPF}_{6}$ in EC: DEC: FEC 45: 45: 10 (by mass). All Si-np||Li cells were cycled between 0.005 and $1.50 \mathrm{~V}$ at a rate of $\mathrm{C} / 20$ for 1 formation cycle, with a $\mathrm{C} / 40$ taper charge followed by cycles at $\mathrm{C} / 3$ with a $\mathrm{C} / 20$ taper charge. Cell cycling was carried out with an Arbin BT 2000 battery cycler at $25^{\circ} \mathrm{C}$. All cells were tested in triplicate. After the $1^{\text {st }}$ lithiation and $2^{\text {nd }}$ and $20^{\text {th }}$ delithiations, cells were rested for 12 hours followed by electrochemical impedance spectroscopy using a potentiostat with an amplitude of $10 \mathrm{mV}$ and frequency range of $300 \mathrm{kHz}-20 \mathrm{mHz}$. Representative data is presented.

Delithiated electrodes were extracted from the cycled cells, carefully rinsed with DMC three times $(1.5 \mathrm{~mL}$ in total) to remove residual electrolyte and then dried in a glove box for ex-situ surface analysis. Ex-situ X-ray photoelectron spectroscopy (XPS) was conducted using a K-Alpha spectrometer (Thermo Scientific) with a spot size of $400 \mu \mathrm{m}$, an energy step size of $0.05 \mathrm{eV}$, and a pass energy of $50 \mathrm{eV}$. The electrodes were transferred from the glove box to the XPS chamber using a vacuum-sealed transfer module (Thermo Scientific) without exposure to air. The binding energy was corrected based on the $\mathrm{C} 1 \mathrm{~s}$ peak of hydrocarbons at $285 \mathrm{eV}$. Infrared spectroscopy with attenuated total reflectance (IR-ATR) (Bruker Tensor 27 with LaDTG detector) was conducted inside a $\mathrm{N}_{2}$-filled glove box to prevent the reactions of samples with $\mathrm{O}_{2}$ and moisture. All spectra were collected with 512 scans at a spectral resolution of $4 \mathrm{~cm}^{-1}$.

\section{Results and Discussion}

The surface modification was carried out as described in the Experimental section and the nanoparticle powders were analyzed by IR-ATR. The spectra of the Si-np and M-Si-np along with pure citric acid powder are provided in Figure 1. Pure citric acid has two characteristic absorptions at 1748 and $1702 \mathrm{~cm}^{-1}$ corresponding to the $\mathrm{C}=\mathrm{O}$ stretch of the carbonyl groups. The carbonyl peaks of the citric acid are shifted upon reaction with the surface of the silicon nanoparticles to 1725 and $1630 \mathrm{~cm}^{-1}$ characteristic of the conversion to silyl esters (-Si-O- C(O)-C-) as previously reported. ${ }^{23,27,28}$

Prior to conducting electrochemical studies, thermogravimetric analysis (TGA) was conducted on the fresh and CA surface modified silicon nanoparticles to determine the quantity of citric acid on the surface of the active material. The results are displayed in Figure 2. Both samples were dried under vacuum and analyzed under nitrogen. The Si-np undergoes no weight loss up to $350^{\circ} \mathrm{C}$, while the M-Si-np has a small weight loss of $\sim 0.7 \%$. Since both samples were processed under similar conditions, the weight loss observed for the M-Si-np can be assigned to the removal of citric acid. The mass loss of citric acid corresponds to approximately one monolayer resulting from the generation of silyl esters (Figure 3).

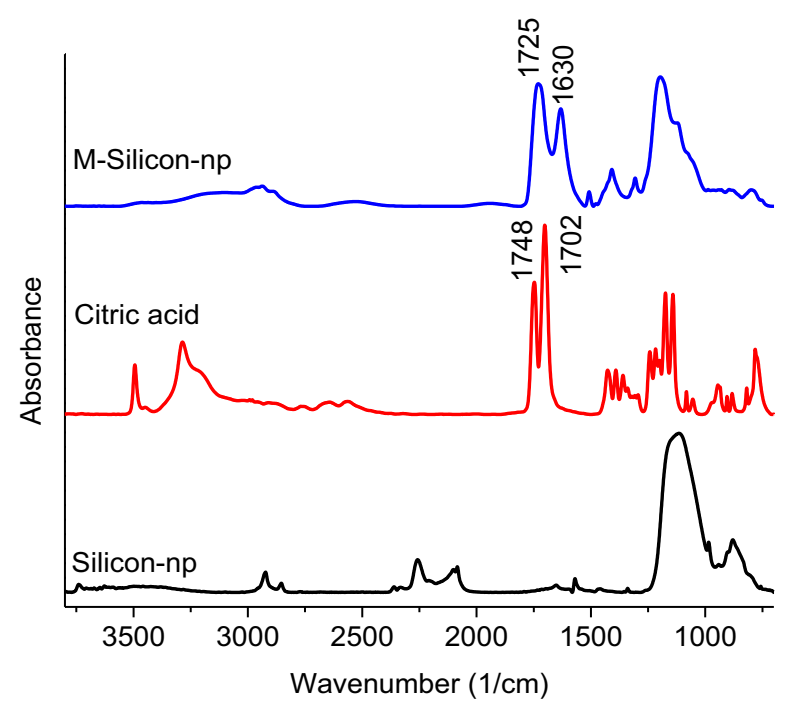

Figure 1. FTIR - ATR spectra of silicon nanoparticles (black), citric acid powder (red) and CA modified silicon nanoparticles (Blue).

\section{Electrochemical Performance}

Silicon nanoparticle (with $50 \% \mathrm{Si}$ ) and silicon nanoparticle graphite (Si-np/Gr) composite electrodes (with $15 \%$ silicon) were prepared with PVDF binder. While PAA binders have been typically reported to improve the performance of silicon anodes, PVDF was selected since the focus of the investigation is on the effect of citric acid modification of the surface of the silicon nanoparticles and the carboxylic acid functional groups of the PAA have similar reactions with the silicon surface as observed for citric acid. ${ }^{23}$ Si-np||lithium cells were constructed and analyzed. Better performance was observed in cells with M-Si-np than the Si-np. The cycling performance data is provided in Figure 4. The first cycle delithiation capacity for M-Si-np is $3550 \mathrm{mAh} / \mathrm{g}$ while the $\mathrm{Si}-\mathrm{np}$ has a first cycle delithiation capacity of $2650 \mathrm{mAh} / \mathrm{g}$. Unfortunately, we do not have a strong understanding of the large increase in capacity at this time. In addition, after the first lithiation, the cells containing Si-np have greater impedance than cells containing M-Si-np. This is consistent with either a more conductive SEI or less damage to the electrode laminate for the MSi-np electrodes. While the first cycle efficiencies are similar for the $\mathrm{M}-\mathrm{Si}-\mathrm{np}$ and Si-np, the second cycle efficiency is much higher for MSi-np (90\%), than Si-np (77\%), suggesting that the M-Si-np generates an SEI after fewer cycles and thus the surface modification results in the generation of a pre-SEI. The change in the first two cycles results in a large improvement in the capacity of the electrode. However, after the first two cycles the capacity loss is similar for the two

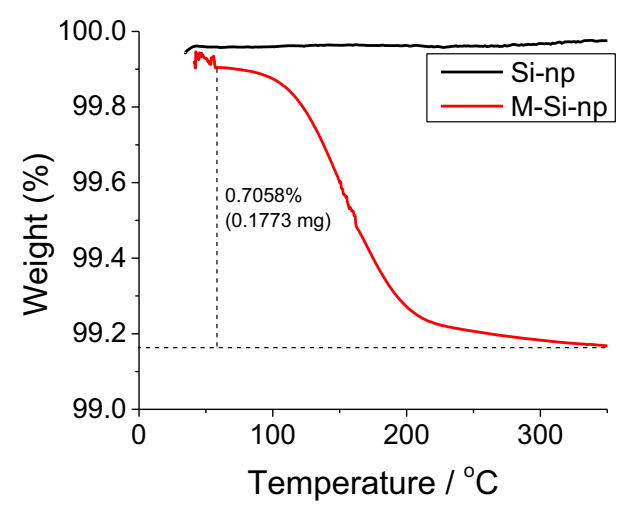

Figure 2. TGA of the fresh silicon nanoparticles (black) and CA surface modified silicon nanoparticles (red). 

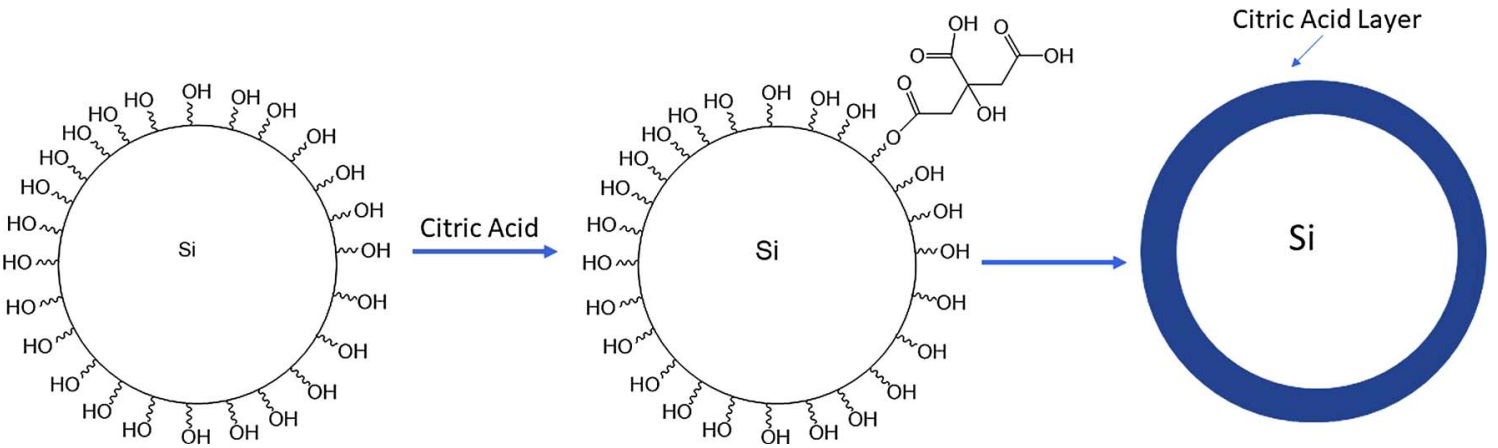

Figure 3. Schematic representation of the surface modification of silicon nanoparticles.

electrodes suggesting that capacity fade from electrode damage during the large volumetric changes upon cycling becomes dominant. However, the overall capacity retention is significantly better for the M-Si-np electrode.

Silicon graphite composite electrodes which contain $15 \%$ silicon have also been prepared and investigated in Si-np/Gr||lithium cells as depicted in Figure 5. The first cycle discharge capacity and efficiency are similar for cells with M- Si-np/Gr and Si-np/Gr. The similarity of
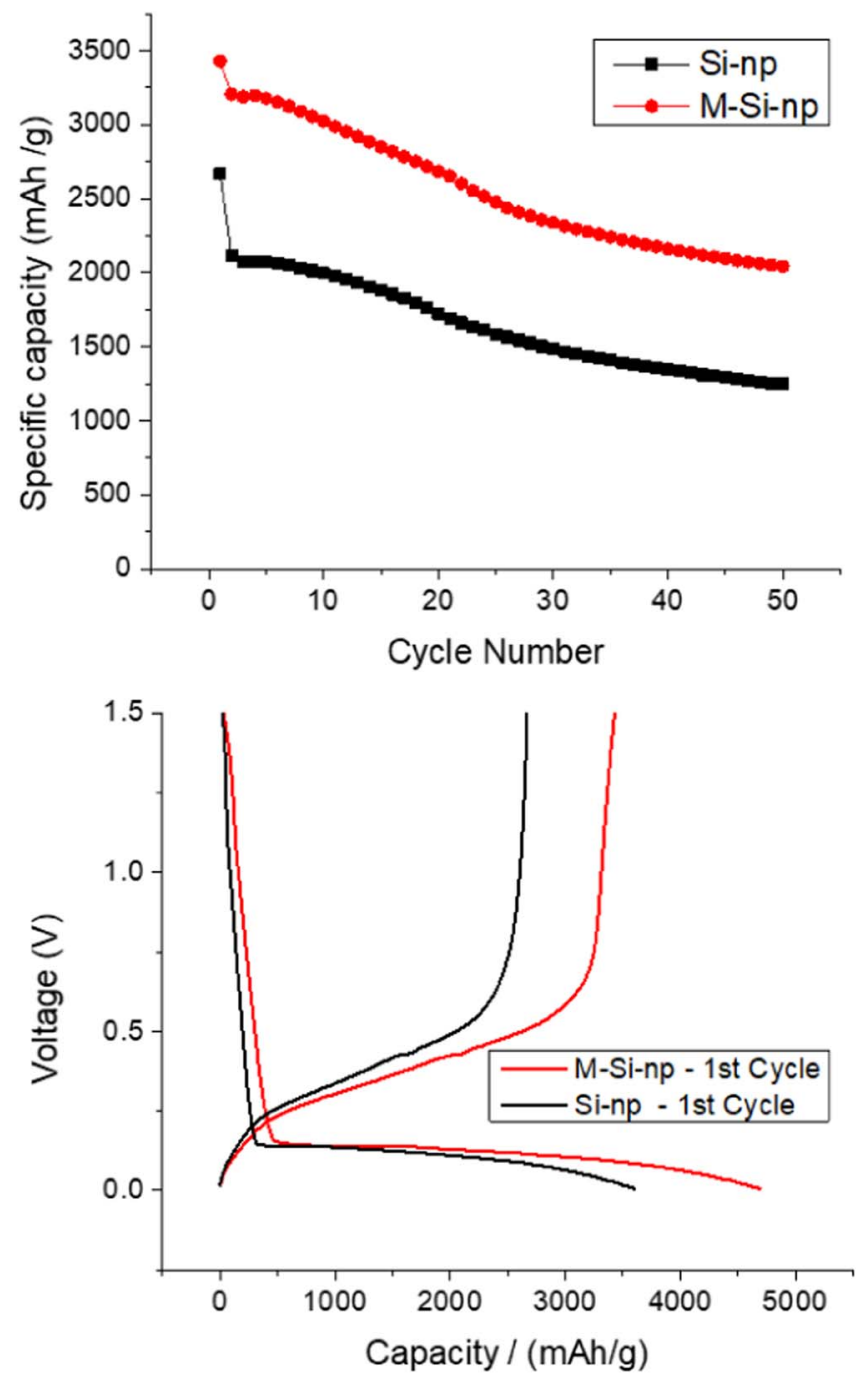

first cycle discharge capacity is surprising when compared to the large increase in capacity for the M-Si-np electrodes compared to the Si-np electrodes as described above. However, this difference may suggest that the capacity difference between the M-Si-np electrodes and S-np electrodes could be due to differences in Si-np isolation, which would be significantly lessened in the composite electrodes. While we do not have a strong understanding of why citric acid modification significantly improves the second cycle efficiency for the Si-np electrodes
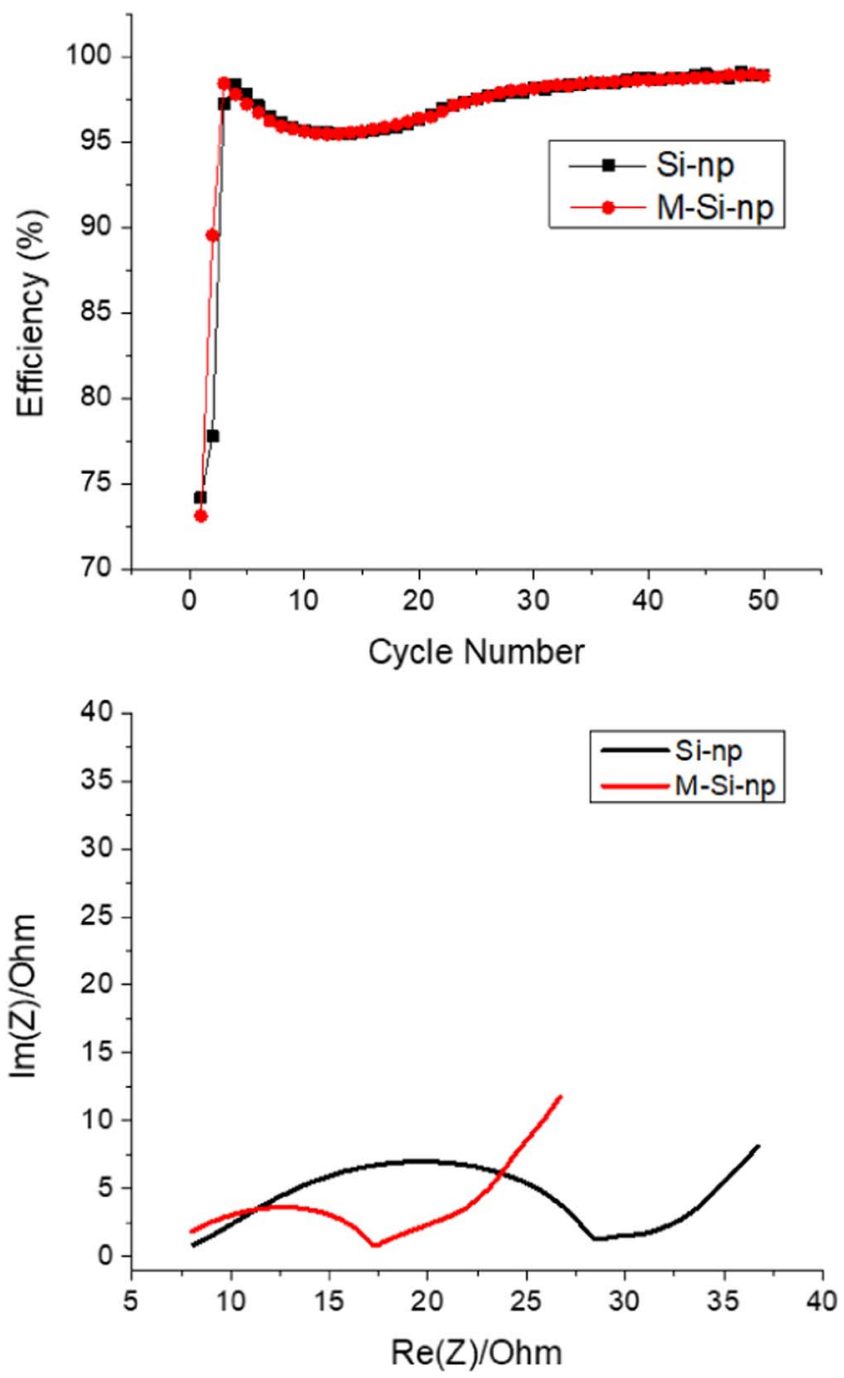

Figure 4. Cycling performance of silicon electrodes a) specific capacity and b) coulombic efficiency vs cycle number plots, c) first cycle voltage profile and d)1st lithiation impedance spectra. 

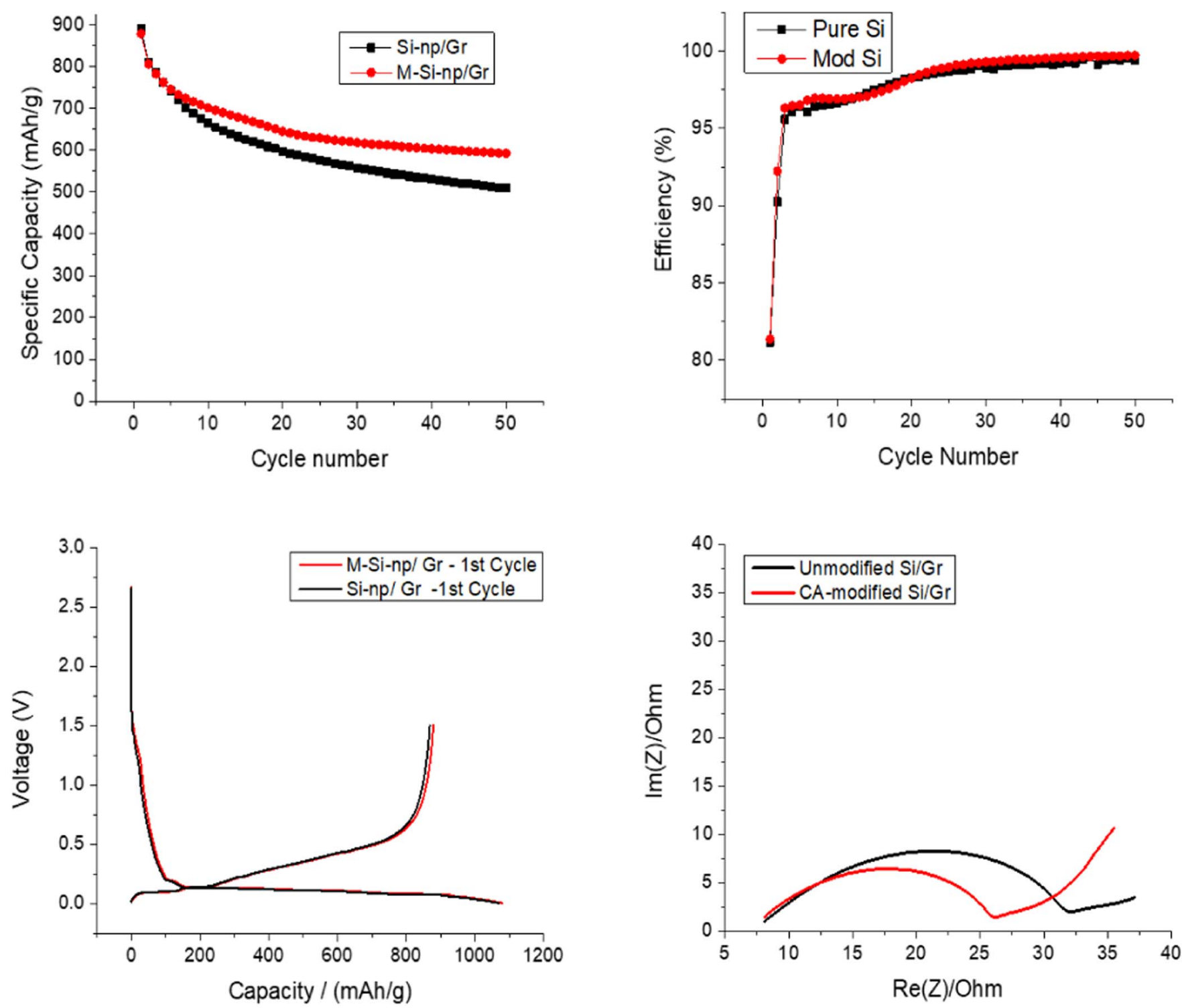

Figure 5. Cycling performance of silicon graphite composite electrodes a) specific capacity and b) coulombic efficiency vs cycle number plots, c) first cycle voltage profile and d)1st lithiation impedance spectra.

and does not change the second cycle efficiency for Si-np/Gr composite electrodes, silicon nanoparticle electrodes have been previously reported to have low efficiency $(<80 \%)$ with PVDF binders, ${ }^{23}$ while silicon/graphite composite electrodes have been reported to have high second cycle efficiencies. ${ }^{29}$ However, the cells containing M-Si-np/Gr have lower impedance after the first cycle, similar to that observed for the EIS for the Si-np electrodes. Upon continued cycling, the cells with $\mathrm{Si}-\mathrm{np} / \mathrm{Gr}$ composite electrodes have more capacity fade than the cells containing M-Si-np/Gr composite electrodes. The cells containing $\mathrm{M}-\mathrm{Si}-\mathrm{np} / \mathrm{Gr}$ have $\sim 70 \%$ capacity retention after 50 cycles while the cells containing Si-np/Gr have only $\sim 50 \%$ capacity retention after 50 cycles. The improved capacity retention of the M-Si-np/Gr composite electrodes is consistent with the reduced impedance after the first cycle and the improved capacity retention of the silicon electrodes.

Surface analysis of the electrodes.-In an effort to develop a better understanding of the source of performance improvement of the citric acid modified silicon particles, ex-situ surface analysis of the electrodes before and after cycling has been conducted. XPS and
IR-ATR spectra of the fresh and cycled electrodes were obtained without exposure to air.

The IR-ATR spectra of the Si-np/Gr composite electrodes and the $\mathrm{M}-\mathrm{Si}$-np/Gr composite electrodes before and after cycling are depicted in Figure 6 . The fresh electrodes have peaks at 1416, 1177, 975,880 and $828 \mathrm{~cm}^{-1}$ characteristic of the PVdF binder. ${ }^{24,30}$ Since the surface modification is only a mono-layer on the silicon particle and there is only $15 \%$ silicon in the composite electrode, the spectra of the fresh electrodes are very similar. The cycled electrodes are all dominated by peaks characteristic of $\mathrm{Li}_{2} \mathrm{CO}_{3}$ at 1420 and 1490 $\mathrm{cm}^{-1}$. In addition, weak absorptions are observed at $1790 \mathrm{~cm}^{-1}$ characteristic of poly(FEC) for all cycled electrodes. ${ }^{24,31}$ After two cycles, the composite electrodes containing M-Si-np have new absorptions at $1590 \mathrm{~cm}^{-1}$ characteristic of $-\mathrm{CO}_{2} \mathrm{Li}$ from lithium citrate as previously reported, ${ }^{24,23}$ consistent with citric acid modification of the SEI.

The XPS spectra of the Si-np/Gr composite electrodes and the MSi-np/Gr composite electrodes before and after cycling are depicted in Figure 7 and the elemental concentrations are provided in Table I. The fresh electrodes are dominated by $\mathrm{C}$ and $\mathrm{Si}$ from the active materials along with high concentrations of $\mathrm{O}$ and $\mathrm{F}$ from the surface coating of $\mathrm{SiO}_{2}$ on the silicon nanoparticles and the PVDF binder, 

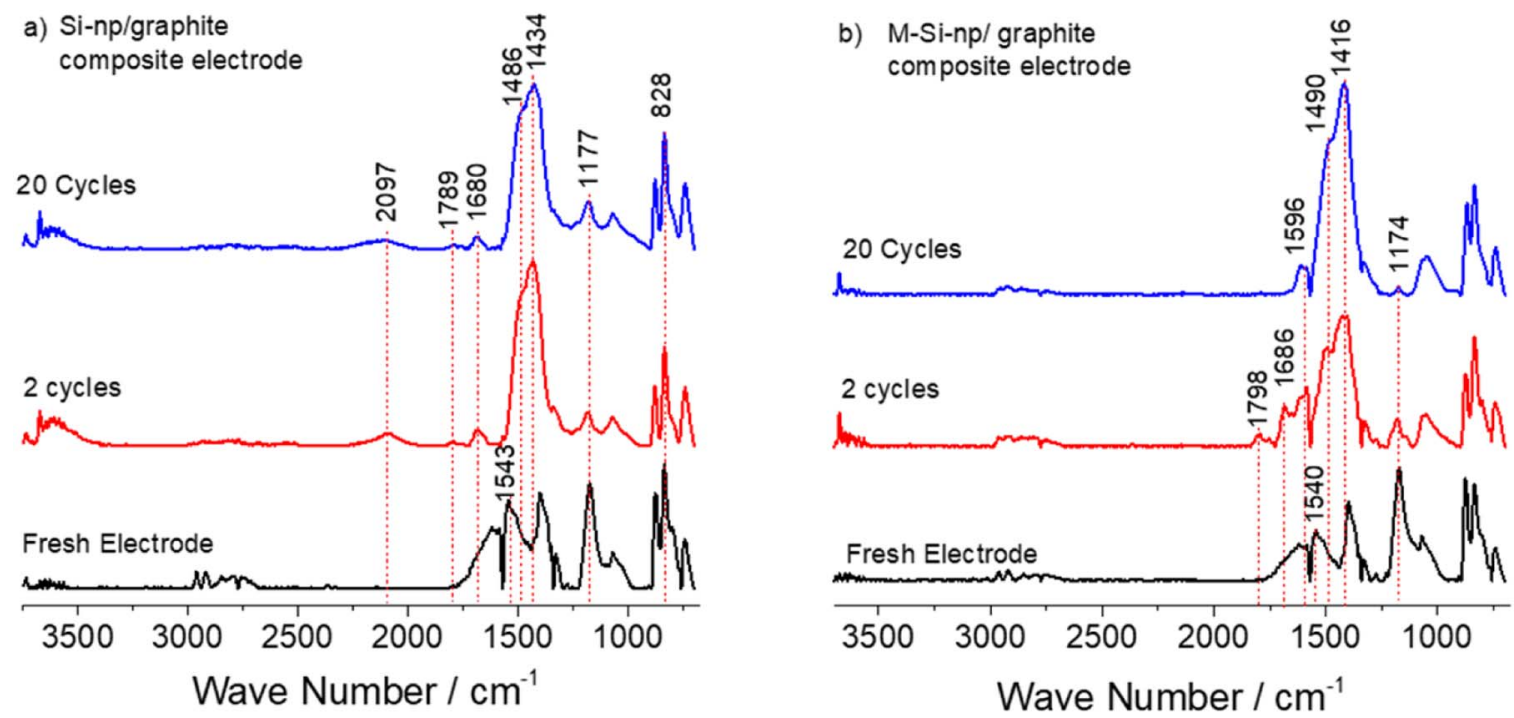

Figure 6. FTIR- ATR data for a) Si-np/Gr and b) M-Si-np/Gr electrodes. (black) fresh electrode, (red) electrode extracted after 2 cycles, (blue) electrode extracted after 20 cycles.

a)

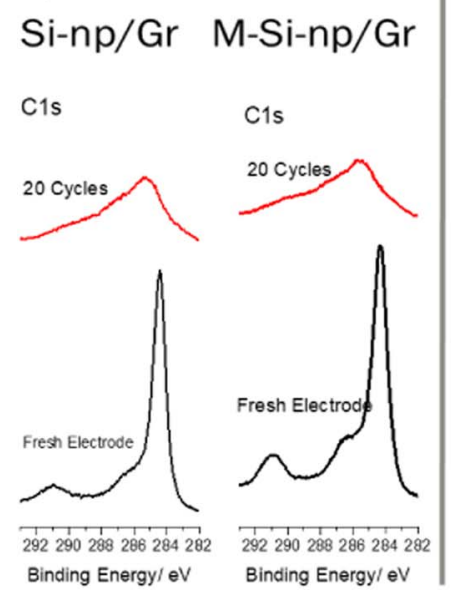

b) Si-np/Gr M-Si-np/Gr

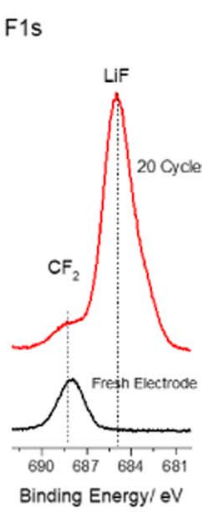

c) Si-np/Gr M-Si-np/Gr

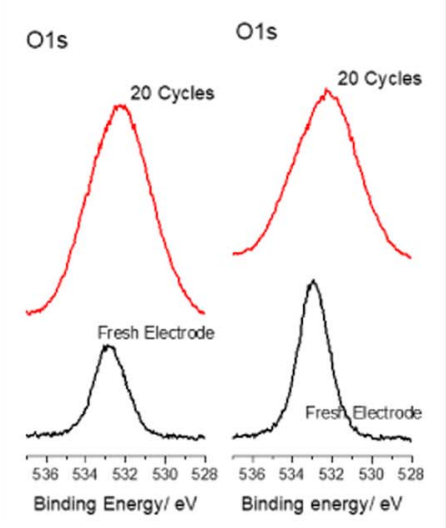

d) Si-np/Gr M-Si-np/Gr

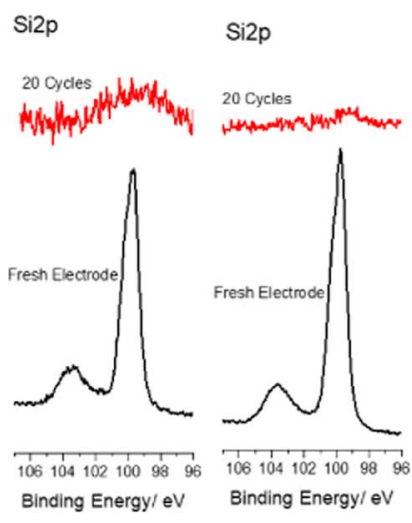

Figure 7. XPS data for silicon nanoparticle and modified silicon nanoparticle electrodes a) C1s, b) F1s, c) Si2p, and d) O1s. Fresh electrode (black), electrodes extracted, (red) after 20 cycles.

respectively. After cycling, the concentrations of $\mathrm{C}$ and $\mathrm{Si}$ are decreased while the concentrations of $\mathrm{Li}, \mathrm{F}$, and $\mathrm{O}$ are increased characteristic of the generation of an SEI on the surface of the anode. The XPS spectra of the fresh electrodes are very similar and are dominated by PVDF binder (C1s, 2.84.3, 286.5 and $291 \mathrm{eV}$; F1s, $687.5 \mathrm{eV}$ ),

Table I. Elemental concentrations obtained by XPS for fresh and cycled ( 20 cycles) Si-np/GR and M-Si-np/Gr electrodes.

Atomic \%

\begin{tabular}{llllll}
\cline { 6 - 6 } & \multicolumn{3}{c}{ Fresh } & & \multicolumn{2}{c}{20 cycles } \\
\cline { 2 - 3 } \cline { 6 - 6 } Element & M-Si-np/Gr & Si-np/Gr & & M-Si-np/Gr & Si-np/Gr \\
\hline C1s & 54.8 & 67.6 & & 24.6 & 24.3 \\
F1s & 12.6 & 8.6 & & 24.8 & 25.5 \\
Li1s & N/A & N/A & & 31.1 & 31.4 \\
O1s & 11.2 & 8.9 & & 18.9 & 17.9 \\
P2p & N/A & N/A & & 0.4 & 0.5 \\
Si2p & 21.4 & 14.9 & & 0.2 & 0.4
\end{tabular}

graphite $(\mathrm{C} 1 \mathrm{~s}, 284.3 \mathrm{eV})$, and silicon $(99.4 \mathrm{eV})$, as expected since the $\mathrm{M}-\mathrm{Si}$-np/Gr electrode contains only a very thin layer of citric acid. The XPS spectra of the electrodes after cycling are very similar. The $\mathrm{C} 1 \mathrm{~s}$ spectrum contains broad $\mathrm{C} 1 \mathrm{~s}$ peak between 287 and $291 \mathrm{eV}$ characteristic of a combination of $\mathrm{C}-\mathrm{O}, \mathrm{C}=\mathrm{O}$, and $\mathrm{CO}_{3}$. After cycling, both electrodes contain a strong peak at $685 \mathrm{eV}$ and a weak peak at $687 \mathrm{eV}$ in the $\mathrm{F} 1 \mathrm{~s}$ spectrum characteristic of $\mathrm{LiF}$ and $\mathrm{Li}_{\mathrm{x}} \mathrm{PF}_{\mathrm{y}} \mathrm{O}_{\mathrm{z}}$, respectively, from the reduction of FEC and $\mathrm{LiPF}_{6} \cdot{ }^{19,32}$ After cycling, the silicon $2 p$ spectra contains only weak peaks consistent with the generation of an SEI which is thicker than the depth of penetration of XPS. The O1s spectra contain a broad peak between 531 and $534 \mathrm{eV}$ characteristic of a combination of $-\mathrm{CO}_{3},-\mathrm{CO}_{2}$, and $\mathrm{C}-\mathrm{O}$, supporting the presence of poly(carbonate), lithium alkyl carbonate, lithium carboxylate, and lithium carbonate. Overall the XPS spectra are similar for both the Si-np/Gr and M-Si-np/Gr electrodes suggesting that the composition of the SEI is similar for both electrodes after 20 cycles. ${ }^{4,33}$

Electrochemical cycling of silicon graphite composite electrodes with $\mathrm{LiCoO}_{2}$ electrodes. - The silicon graphite composite electrodes were further investigated in full cells with a $\mathrm{LiCoO}_{2}$ cathode to examine the effect of the surface modification in cells with a 

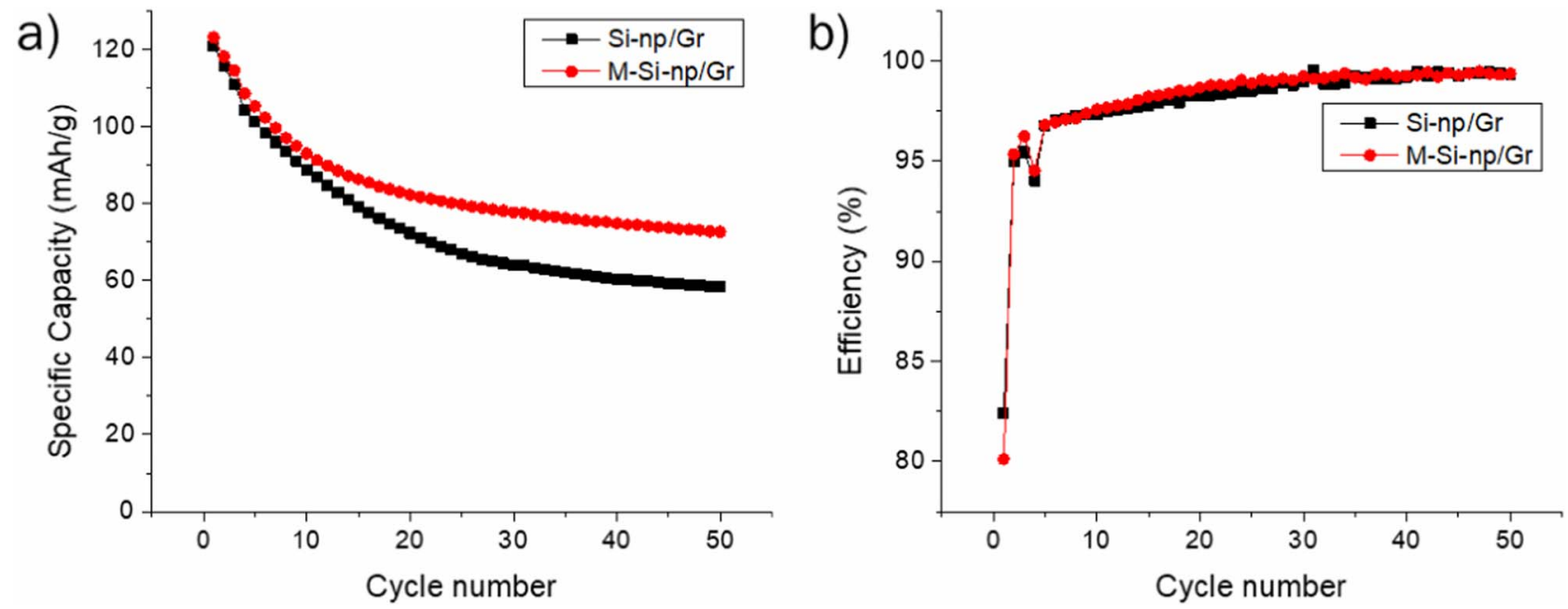

Figure 8. Cycling performance data for Silicon graphite composite electrode/ LCO full cells, a) specific capacity and b) coulombic efficiency vs cycle number.

limited supply of lithium for cycling. $\mathrm{LiCoO}_{2}$ electrodes are commonly used in many commercial lithium ion batteries due to excellent capacity retention. ${ }^{34,35}$ Electrochemical cycling of silicon graphite composite || $\mathrm{LiCoO}_{2}$ cells have been conducted with the same electrolyte and similar cycling protocol to the silicon graphite composite/lithium cells discussed above. The cycling performance of the graphite silicon composite || $\mathrm{LiCoO}_{2}$ cells containing M-Si-np or Si$\mathrm{np}$ is depicted in Figure 8. The cycling performance is similar to that observed for the Si-np/Gr composite||lithium cells. The cells containing M-Si-np have significantly better capacity retention (78\%) than the cells containing Si-np $(60 \%)$. The results suggest that surface modification of silicon nanoparticles may improve the performance of silicon graphite composite electrodes in commercial cells.

\section{Conclusions}

Surface modification of silicon nanoparticles with citric acid, a small molecule tricarboxylic acid, has been investigated to generate a more stable SEI and reduce electrolyte consumption during the lithiation and delithiation of silicon electrodes. The study has shown improved performance for the surface modified silicon-based electrodes due to the formation of the pre-SEI. The surface modified $\mathrm{Si}$-np/Gr composite/lithium cells have much better capacity retention, $60 \%$, than the unmodified Si-np/Gr composite||lithium cells, $45 \%$, after 50 cycles. The surface modified $\mathrm{Si}-\mathrm{np} / \mathrm{Gr}$ composite || $\mathrm{LiCoO}_{2}$ cells also have much better capacity retention, $78 \%$, compared to the unmodified Si-np/Gr composite || $\mathrm{LiCoO}_{2}$ cells. The results suggest that surface modification of the silicon nano-particles with citric acid can significantly improve the performance of silicon/graphite composite electrodes.

\section{Acknowledgments}

The authors gratefully acknowledge funding from Department of Energy Office of Basic Energy Sciences EPSCoR Implementation award (DE-SC0007074).

\section{ORCID}

Sunhyung Jurng (D) https://orcid.org/0000-0003-0780-0935

Brett L. Lucht (iD https://orcid.org/0000-0002-4660-0840

\section{References}

1. M. Armand and J. M. Tarascon, Nature, 451, 652 (2008).

2. K. Xu, Chem. Rev., 114, 11503 (2014).
3. D. Aurbach, Y. Talyosef, B. Markovsky, E. Markevich, E. Zinigrad, L. Asraf, J. S. Gnanaraj, and H. J. Kim, Electrochim. Acta, 50, 247, (2004).

4. K. W. D. K. Chandrasiri, C. C. Nguyen, Y. Zang, B. S. Parimalam, and B. L. Lucht, Electrochemica acta, 250, 285, (2017).

5. X. Shen, Z. Tian, R. Fan, L. Shao, D. Zhang, G. Cao, L. Kou, and Y. Bai, Journal of Energy Chemistry, 27(4), 1067, (2018).

6. S. Goriparti, E. Miele, F. De Angelis, E. Di Fabrizio, R. Proietti Zaccaria, and C. Capiglia, J. Power Sources, 257, 421, (2014).

7. X. B. Cheng, R. Zhang, C. Z. Zhao, F. Wei, J. G. Zhang, and Q. Zhang, Advanced Science, 3(3), 1500213, (2016).

8. F. Luo, B. Liu, J. Zheng, G. Chu, K. Zhong, H. Li, X. Huang, and L. Chen, J. Electrochem. Soc., 162(14), A2509, (2015).

9. X. Zuo, J. Zhu, P. Müller-Buschbaum, and Y. J. Cheng, Nano Energy, 31, 113, (2017).

10. K. Xu, Chem. Rev., 104, 4303 (2004).

11. B. Scrosati and J. Garche, J. Power Sources, 195, 2419 (2010).

12. K. M. Abraham, J. Phys. Chem. Lett., 6, 830 (2015).

13. W. J. Zhang, J. Power Sources, 196, 13 (2011)

14. S. D. Beattie, M. J. Loveridge, M. J. Lain, S. Ferrari, B. J. Polzin, R. Bhagat, and R. Dashwood, J. Power Sources, 302, 426, (2016).

15. M. N. Obrovac and L. J. Krause, J. Electrochem. Soc., 154, A103 (2007).

16. D. Mazouzi, Z. Karkar, C. R. Hernandez, P. J. Manero, D. Guyomard, L. Roué, and B. Lestriez, J. Power Sources, 280, 533, (2015).

17. N. Kim, C. Oh, J. Kim, J. Kim, D. Jeong, J. Bae, E. Hong, and J. Kyoo, J. Electrochem. Soc, 164(1), 6075, (2017).

18. T. Yoon, C. C. Nguyen, D. M. Seo, and B. L. Lucht, J. Electrochem. Soc., 162, A2325, (2015).

19. C. C. Nguyen and B. L. Lucht, J. Electrochem. Soc., 161, A1933 (2014).

20. A. Magasinski, B. Zdyrko, I. Kovalenko, B. Hertzberg, R. Burtovyy, C. F. Huebner, T. F. Fuller, I. Luzinov, and G. Yushin, ACS Appl. Mater. Interfaces, 2(11), 3004, (2010).

21. M. J Lacey, F. Jeschull, K. Edstrom, and D. Brandell, J. Power Sources, 264, 8, (2014).

22. V. L. Chevrier, L. Liu, D. B. Le, J. Lund, B. Molla, K. Reimer, L. J. Krause, L. D. Jensen, E. Figgemeier, and K. W. Eberman, J. Electrochem. Soc., 161(5), A783, (2014).

23. C. C. Nguyen, T. Yoon, D. M. Seo, P. Guduru, and B. L. Lucht, ACS Appl. Mater Interfaces, 8(19), 12211, (2016).

24. W. Porcher, S. Chazelle, A. Boulineau, N. Mariage, J. P. Alper, T. Van Rompaey, J. Bridel, and C. Haon, J. Electrochem. Soc., 164(14), 3633, (2017).

25. C. C. Nguyen, D. M. Seo, K. W. D. K. Chandrasiri, and B. L. Lucht, Langmuir, 33(37), 9254, (2017).

26. L. a. Aslanov, V. N. Zakharov, M. a. Zakharov, a. L. Kamyshny, S. Magdassi, and a. V. Yatsenko, Russ. J. Coord. Chem., 36(5), 330, (2010).

27. S. C. Feifel and F. Lisdat, J. Nanobiotechnology, 9, 59 (2011).

28. S. J. García, H. R. Fischer, P. A. White, J. Mardel, Y. González-García, J. M. C. Mol, and A. E. Hughes, Prog. Org. Coatings, 70(2-3), 142, (2011).

29. T. Schott, J. L. G, P. Nov, and S. Trabesinger, J. Electrochem. Soc, 164(2) A190 (2017).

30. J. K. Papp, J. D. Forster, C. M. Burke, H. W. Kim, A. C. Luntz, R. M. Shelby, J. J. Urban, and B. D. McCloskey, J. Phys. Chem. Lett., 8(6), 1169, (2017).

31. R. Jung, M. Metzger, D. Haering, S. Solchenbach, C. Marino, N. Tsiouvaras, C. Stinner, and H. A. Gasteiger, J. Electrochem. Soc., 163(8), A1705 (2016).

32. L. A. Brown, J. L. Rhinehart, and B. K. Long, ACS Catal., 5(10), 6057, (2015).

33. S. Leroy, F. Blanchard, R. Dedryvère, H. Martinez, B. Carré, D. Lemordant, and D. Gonbeau, Surf. Interface Anal., 37(10), 773, (2005).

34. B. Huang, Y. Jang, Y. Chiang, and D. R. Sadoway, J. Appl. Electrochem., 28(3), 1365, (1998).

35. C. M. Julien, A. Mauger, K. Zaghib, and H. Groult, Inorganics, 2, 132, (2014) 